\title{
Efektivitas Kebijakan Pengelolaan Sampah Berbasis Tempat Pengelolaan Sampah Terpadu 3R di Indonesia
}

\section{The Effectiveness of Waste Management Policy Based on Integrated Waste Management Site 3R in Indonesia}

\author{
Fallita Rahma Wati*, Alfin Rizqi, M. Iqbal, Sabriani Sangga Langi\& \\ Dila Noviza Putri \\ Ilmu Pemerintahan, Fakultas Ilmu Sosial dan Ilmu Politik, \\ Universitas Muhammadiyah Malang, Indonesia
}

Diterima: 28 September 2020; Disetujui:15 Desember 2020; Dipublish:31 Januari 2021

\begin{abstract}
Abstrak
Penelitian ini bertujuan untuk mengidentifikasi dan menganalisis bagaimana efektivitas kebijakan pengelolaan sampah berbasis Tempat Pengelolaan Sampah Terpadu (TPST) 3R di Indonesia serta sebagai dasar pertimbangan dan evaluasi bagi pemerintah pusat maupun daerah dalam membuat kebijakan pengelolaan sampah. Hal ini disebabkan karena pengelolaan sampah baik skala nasional maupun daerah masih belum menemukan solusi yang tepat, ditambah dengan populasi yang terus bertambah, sehingga menjadi penting untuk mencari pengelolaan sampah yang tepat. Metode penelitian ini menggunakan pendekatan kualitatif dengan melakukan studi literatur dari berbagai macam sumber yang relevan. Hasil penelitian ini menunjukkan bahwa kebijakan pengelolaan sampah berbasis TPST 3R belum optimal dalam pelaksanaannya. Efektivitas kebijakan pengelolaan sampah tersebut diukur melalui Teori Campbell dengan beberapa indikator yaitu keberhasilan program, keberhasilan sasaran, kepuasan terhadap program, kesesuaian input dan output, dan pencapaian tujuan menyeluruh.
\end{abstract}

Kata Kunci: Efektivitas, Pengelolaan Sampah, Tempat Pengelolaan Sampah Terpadu (TPST) 3R

Abstract

This study aims to identify and analyze the effectiveness of waste management policies based on the $3 R$ Integrated Waste Management Site (TPST) in Indonesia and as a basis for consideration and evaluation for the central and local governments in making waste management policies. This is because waste management both at national and regional scales has not yet found the right solution, coupled with a growing population, so it is important to find appropriate waste management. This research method uses a qualitative approach by conducting literature studies from various relevant sources. The results of this study indicate that the TPST 3R-based waste management policy has not been optimal in its implementation. The effectiveness of the waste management policy is measured through Campbell's theory with several indicators, namely program success, target success, program satisfaction, suitability of input and output, and achievement of overall goals.

Keywords: Effectiveness, Waste Management, Integrated Waste Management Site (TPST)

How to Cite: Fallita R, W. Alfin, R, Iqbal, M, Sabriani, S.L, \& Dila, N.P. (2021). Efektivitas Kebijakan Pengelolaan Sampah Berbasis Tempat Pengelolaan Sampah Terpadu (TPST) 3R di Indonesia. PERSPEKTIF, 10 (1): 195-203

*Corresponding author:

E-mail: Fallitarahma@gmail.com
ISSN 2085-0328 (Print)

ISSN 2541-5913 (online) 


\section{PENDAHULUAN}

Sampah masih menjadi masalah yang kerap kali dihadapi dalam skala nasional bahkan dalam lingkup lebih kecil lagi yakni di daerah. Populasi manusia yang meningkat setiap tahunnya tentu akan menghasilkan sampah yang sebanding pula akibat dari sisasisa aktivitas manusia. Peningkatan volume sampah yang terjadi tanpa diimbangi kesadaran akan pengelolaan sampah yang baik tentu akan membawa permasalahan lain terutama bagi lingkungan. Berdasarkan data yang dikutip dalam laman berita Katadata bahwa sampah yang menggunung setiap jam berjumlah 7300-ton sampah yang setara dalam satu jam tumpukan sampah dapat menutupi setengah dari tinggi Monas (Pradityo et al., 2019).

Permasalahan sampah ditambah dengan kesadaran upaya pemilahan sampah dari masyarakat yang masih rendah. Kesadaran masyarakat rendah, kurangnya sarana dan prasarana serta kurangnya tenaga profesional menjadi hal yang masih dijumpai di Indonesia sehingga tidak mengherankan jika pengelolaan sampah masih belum berjalan secara optimal. Beberapa pengelolaan sampah didaerah yang mengalami permasalahan yaitu masyarakat terutama yang tinggal di sekitar TPA Tlekung Kota Batu yang mengeluhkan bau menyengat dari sampah yang menurut Daerah Pemilihan (Dapil) 3 DPRD karena kurang optimal dan disiplin dalam pengelolaan sampah (Momentum, 2020). Tumpukan sampah masih menggunung di sekitar jalan menghubungkan kecamatan Ciledug dengan kecamatan Babakan. Bahkan tumpukan sampah tersebut berada ditempat yang sudah terdapat papan larangan untuk membuang sampah yang berdampak pada munculnya bau menyengat di daerah tersebut. Kesadaran masyarakat masih sangat rendah terhadap pentingnya membuang sampah di tempat yang sudah disediakan pemerintah (Den, 2020)

Di Indonesia sendiri Peraturan tentang pengelolaan sampah sudah diatur dalam UU Nomor 18 Tahun 2008. Undang undang tersebut juga sebagai acuan untuk setiap daerah di Indonesia memiliki regulasi dalam konteks wilayah regional karena telah ada amanat terkait desentralisasi dan otonomi daerah yang dimana daerah memiliki kewenangan sendiri untuk mengatur daerahnya, salah satunya memiliki peraturan terkait kelestarian lingkungan dengan cara mengolah sampah. Oleh karena melalui tulisan ini penulis akan meneliti terkait bagaimana efektivitas kebijakan pengelolaan sampah berbasis TPST 3R yang ada di Indonesia apakah sudah berjalan secara maksmimal atau belum. Hal ini bertujuan untuk memberikan bahan pertimbangan dan evaluasi kepada pemerintah terutama kebijakan pengelolaan sampah yang terus mengalami peningkatan setiap tahun.

Efektivitas adanya kebijakan pengelolaan sampah berbasis TPST 3R yang pernah dilakukan di beberapa kota sebelumnya juga masih kurang efektif dalam pelaksanaanya, seperti di TPST di Desa Tawangsari, Kabupaten Boyolalali (Nugraheni \& Widjonarko, 2019) dimana dalam aspek ekonomi TPST Tawangsari pada tahun 2018 cenderung merugi dimana produk sampah yang ada belum dimaksimalkan dengan baik untuk menambah pendapatan. Dari segi Kelembagaan yakni SDM yang banyak namun tidak dapat diandalkan untuk menjamin kegiatan berjalan teratur. Dari segi aspek sosial budaya yakni keterlibatan masyarakat juga masih kurang baik dari keterlibatan pemilahan sampah hingga keterlibatan dalam mematuhi aturan pembuangan sampah. Sehingga TPST Tawangsari masuk ke dalam kategori yang kurang berkelanjutan atau tidak efektif dalam menjalankan TPST ini.

Selain itu kebijakan pengelolaan sampah berbasis TPST 3R di Kabupaten Sidoarjo juga belum berjalan secara efektif (Suning \& Muryanto, 2016). Hal ini dapat dilihat dari segi kelembagaan dimana masih belum ada sinergitas antara dinas, swasta dengan masyarakat terkait kegiatan di TPST. Partisipasi masyarakat masih sangat rendah serta bergantung pada pemerintah.

Kebijakan pengelolaan sampah di Kota Palu juga belum maksimal (Rendy, 2015), hal ini ini disebabkan kurangnya kontrol dari pihak yang bersangkutan dan kesadaran masyarakat dalam pengelolaan sampah, kemudian efisiensi belum tercapai karena perilaku dan kesadaran masyarakat terhadap lingkungan yang masih rendah, selain itu waktu operasional pembuangan sampah yang ditentukan belum sepenuhnya dipatuhi oleh masyarakat, sedangkan kriteria kecukupan juga belum dapat memecahkan masalah kebersihan dan kesehatan lingkungan karena keberadaan TPS, TPST dan Bank Sampah hanya menimbulkan bau busuk di lingkungan 
sekitar sehingga secara tidak langsung dapat mempengaruhi tingkat kebersihan dan kesehatan masyarakat.

Teori yang digunakan untuk mengukur keefektivitasan kebijakan pengelolaan sampah berbasis TPST 3R di Indonesia yaitu Teori Efektivitas Campbell dalam (Dwi Febria Zulfa et al., 2019), yang mengukur keefektivitasan kebijakan melalui beberapa indikator, yaitu: 1) Keberhasilan Program; 2) Keberhasilan sasaran; 3) Kepuasan Terhadap Program; 4) Kesesuaian Input dan Output; 5) Pencapaian Tujuan Menyeluruh

\section{METODE PENELITIAN}

Penelitian ini menggunakan Mixed Methods Research. Metode ini memadukan antara pendekatan kuantitatif dan kualitatif dalam proses penelitian. Penelitian ini menggunakan studi kepustakaan dimana menggunakan berbagai referensi yang relevan dengan topik yang diangkat baik buku maupun jurnal. Selain menggunakan studi kepustakaan, dalam penelitian ini juga menggunakan teknis survei untuk memperoleh data yang akurat dari subjek yang berkaitan. Survei dilakukan melalui google form pada 14 Mei 2020.

Dalam penelitian ini peneliti mengumpulkan data dari beberapa kota di Indonesia yang mengimplementasikan TPST 3R dalam pengelolaan sampahnya. Selain mengumpulkan dari jurnal, peneliti juga mengambil sampel salah satu kota yang mengimplementasikan TPST 3R dalam pengelolaan sampah yaitu TPST 3R di Kelurahan Dadaprejo, Kota Batu.

\section{HASIL DAN PEMBAHASAN}

Efektivitas Pengelolaan Sampah Berbasis TPST 3R di Indonesia berdasarkan Teori Efektivitas Campbell

Keberhasilan Program. Keberhasilan suatu program tergantung bagaimana program tersebut dapat dilaksanakan dan digunakan dengan tepat, serta bermanfaat bagi masyarakat Keberhasilan Program TPST 3R dapat dikatakan berhasil di beberapa kota di Indonesia yakni di TPST 3R Mulyoagung, Malang dan Kota Bantul.

Keberhasilan Program TPST 3R Desa Mulyoagung. Keberhasilan program dalam Jurnal ini ialah bahwa TPST - 3R menjadi solusi untuk mengatasi permasalahan pada desa Mulyoagung. Melalui konsep TPST 3R ini dapat memberdayakan masyarakat di desa tersebut. pemberdayaan masyarakat yang dilaksanakan di desa Mulyoagung telah berjalan dengan baik hal tersebut terbukti dengan besarnya antusias warga bila ada kegiatan yang dilaksanakan pemerintah desa berkaitan dengan TPST 3R. adapun didirikannya TPST Mulyoagung dengan tujuan untuk mempertahankan dan menjaga lingkungan agar tidak tercemar akibat sampah, kemudian dalam segi ekonomi dapat membuka peluang lapangan kerja baru bagi masyarakat. dan ketiga dalam sektor pendidikan dimana masyarakat memberikan ruang bagi para pelajar untuk melakukan riset atau penelitian. dan pembangunan TPST 3R ini juga dibangun untuk menyesuaikan visi dan misi desa tersebut yakni menciptakan kesehatan masyarakat dengan lingkungan yang bersih. keberhasilan dari program TPST 3R juga dapat dilihat dari keinginan masyarakat untuk menciptakan model sampah yang modern dan lebih meningkatkan dan menggugah masyarakat agar hidup bersih dan membuang sampah sesuai dengan jenisnya agar mudah diolah dan dijadikan sebagai sumber mata pencaharian ekonomi masyarakat desa Mulyoagung. (Sahputra \& Srihardjono, 2018)

Keberhasilan Program TPST 3R di Kota Bantul. Program dengan konsep 3R dalam jurnal ini dapat dikatakan berhasil di laksanakan, dengan konsep 3R tersebut masyarakat dapat menunjang perekonomian dengan mengandalkan konsep $3 \mathrm{R}$ tersebut. dengan konsep 3R ini masyarakat dapat memilah sampah rumah tangga yang dihasilkan sesuai dengan jenisnya kemudian dalam pengelolaan sampah, masyarakat didampingi oleh dinas lingkungan hidup Bantul yang dapat meningkatkan kemampuan kelompok pengelola sampah dalam mengelola sampah, operasional bank sampah dan pengenalan kegiatan administrasi bank sampah. melalui program pengelolaan berbasis $3 \mathrm{R}$ memberikan solusi bagi sebagian permasalahan sampah. Juga melalui Program TPST 3R ini masyarakat memiliki kemampuan teknisi baru dalam melakukan daur ulang sampah untuk dijadikan sebagai sumber pendapatan ekonomi masyarakat (Budi Setianingrum, 2018)

Keberhasilan Program TPST 3R di Desa Karanganyar. Keberhasilan program TPTS 3R yang diperlihatkan oleh Desa karangan anyar tepatnya pada masyarakat RW 06 dalam menanggulangi permasalahan banjir yang 
sering terjadi di Desa tersebut diakibatkan oleh kebiasaan masyarakat yang membuang sampah ke sungai. Desa Karanganyar bersama pihak swasta yakni PT Pertamina EP Jatibarang Field dan CARE LPPM IPB dalam mendirikan Bank Sampah sebagai solusi dari permasalahan yang ada di Desa Karanganyar serta memberdayakan masyarakat sebagai wujud program CSR perusahaan yakni kepedulian terhadap lingkungan. Dalam jurnal ini lebih memaparkan keberhasilan pendirian bank sampah kepada masyarakat, pengelolaan sampah yang dilakukan berbasis 3R dimana adanya pengelolaan kembali sampah yang ada seperti sampah organik yang di produksi menjadi pupuk organik sementara sampah anorganik diolah menjadi kerajinan atau cinderamata yang unik dapat dijadikan sebagai buah tangan. Dari pengelolaan sampah tersebut masyarakat memperoleh pendapatan ekonomi secara mandiri selain itu program ini dilakukan untuk meningkatkan kapabilitas atau keterampilan masyarakat dalam melihat sampah tidak hanya sebagai hal yang tidak bernilai tetapi jika diolah akan menghasilkan sebuah karya dan dapat dipasarkan dan perjual belikan sehingga memperoleh pendapatan ekonomi secara kreatif.

Berdasarkan paparan di atas dapat menggambarkan keberhasilan program dilakukan sedikit menyentuh karakteristik yang dikemukakan Van Meter dan Horn seperti ada ukuran dan tujuan dari kebijakan atau program yang dijalankan yakni mengurangi jumlah volume sampah dan memberdayakan masyarakat. kemudian ada sumber - sumber kebijakan atau program yakni berasal dari sumber daya manusia, biaya dan waktu yang diperlukan. Sumber daya manusia sangat penting sebagai sumber penggerak dan pelaksana kebijakan, kemudian ada keberhasilan kebijakan atau program yang diperoleh karena adanya kerjasama yang baik antar lembaga dan masyarakat yakni pemerintah desa/kelurahan dan masyarakat setempat. Kemudian komunikasi antar sesame pelaksana sehingga memiliki tujuan yang sama yang akan dihasilkan dari program yang dijalankan

Keberhasilan Sasaran. Apabila sasaran yang telah ditetapkan sebelumnya tidak tercapai atau tidak sesuai dengan target yang telah ditetapkan, maka dikatakan tidak efektif. Sebaliknya, jika sasaran yang telah ditetapkan sebelumnya berhasil dicapai maka hal itu dikatakan efektif. Penentuan sasaran yang dilakukan oleh individu maupun secara organisasi akan sangat menentukan keberhasilan aktivitas organisasi dan sebaliknya jika sasaran yang ditetapkan itu kurang tepat, maka akan menghambat pelaksanaan berbagai kegiatan itu sendiri. Adapun keberhasilan sasaran adanya TPST 3R diberbagai kota di Indonesia sebagai berikut:

Keberhasilan Sasaran di Kota Pekanbaru. Problematika dalam manajemen pengelolaan sampah kota Pekanbaru tahun 2016 dimana Sasaran dan tindakan yang direncanakan oleh Dinas Kebersihan dan Pertamanan terealisasi sebesar 92, 56\% dan penyerapan anggaran sebesar $84,87 \%$. Temuan menarik yaitu tidak terselenggaranya kegiatan Bimbingan Teknis Persampahan Reduce, Reuse, dan Recycle (3R) dengan target 120 Orang dari seluruh kelurahan se Kota Pekanbaru. Sehingga aspek pemberdayaan masyarakat terkait Reduce, Reuse, dan Recycle (3R) tidak optimal terlaksana. Begitu juga dengan kegiatan peningkatan peran serta masyarakat dalam pengelolaan sampah khususnya program K3 di 58 Kelurahan yang terlaksana $100 \%$ namun rendah penyerapan anggaran yang hanya $41 \%$ (Isril \& Febrina, 2017).

Keberhasilan Sasaran di Kabupaten Sidoarjo. Dari jurnal kebijakan keberlanjutan pengelolaan persampahan kabupaten Sidoarjo berbasis TPST terdapat 43 TPST yang sudah terbangun yang dapat dikatakan aktif sejumlah 17 TPST dan yang sudah jadi percontohan adalah 1 TPST yaitu TPST di desa Janti Kecamatan Waru. TPST aktif yang dimaksud sebenarnya masih belum optimal operasionalnya. Sehingga perlu mendapat perhatian dari semua pihak untuk dioperasikan secara optimal, termasuk prasarana dan sarana serta sumber daya manusia yang masih kurang lengkap di TPST. Terlihat bahwa TPST yang terbangun belum dioptimalkan dengan baik sehingga kebijakan ini dapat dikatakan belum berjalan secara efektif dan bahkan dapat membuang anggaran pemerintah karena target yang ada belum tercapai (Suning \& Muryanto, 2016).

Keberhasilan Sasaran di Kota Tenggarong. Implementasi Kebijakan Pengelolaan Sampah yang ada di Tenggarong 
pada Dinas Kebersihan dan Pertamanan Kabupaten Kutai Kartanegara (Tenggarong) belum mencapai hasil yang optimal. Pengolahan Sampah yang ada di TPA Bekotok Tenggarong ini masih belum maksimal karena sampah yang ada hanya dibuat kompos dan gas metan yang produksinya masih terbatas sehingga hanya bisa dimanfaatkan oleh segelintir warga sekitar TPST/TPA Bekotok Tenggarong. Seharusnya hasil dari pengelolaan sampah ini mampu dimanfaatkan oleh masyarakat secara luas tanpa terkecuali dan tanpa terganggu karena alasan keterbatasan sarana prasarana karena ini sudah menjadi tanggungjawab pemerintah untuk memastikan semua berjalan secara 199ancer. (Sari et al., 2018)

Kepuasan Terhadap Program. Untuk mengukur kepuasan terhadap program yang dikeluarkan pemerintah yaitu dengan cara melihat respon dari masyarakat. Masyarakat merupakan salah satu alat ukur untuk melihat sejauh mana keberhasilan suatu program. Maka dari itu penelitian kami salah satu nya menggunakan sampel masyarakat yang memiliki di kelurahannya terdapat TPST 3R. Kami melakukan pengambilan sampel di kelurahan Dadaprejo Kota Batu. Hasil yang kami temukan dari penelitian tersebut dapat dilihat pada tabel 1.

Tabel 1. Kepuasan Masyarakat Terhadap Program TPST 3 R Kelurahan Dadaprejo

\begin{tabular}{|c|c|c|c|c|c|c|c|}
\hline Nama & Ami & Dewi Budiati & Mimin & Siti Alimah & Misyanto & Kusyairi & Fadhilla Nur \\
\hline Usia & 54 & 51 & 45 & 40 & 55 & 53 & 21 \\
\hline Pekerjaan & IRT & IRT & IRT & IRT & $\begin{array}{l}\text { Tukang } \\
\text { Bangunan }\end{array}$ & $\begin{array}{l}\text { Karyawan } \\
\text { Swasta }\end{array}$ & Mahasiswa \\
\hline $\begin{array}{l}\text { Pendirian } \\
\text { TPST } 3 \mathrm{R} \\
(\mathrm{S} / \mathrm{TS})\end{array}$ & $\mathrm{S}$ & $\mathrm{S}$ & $\mathrm{S}$ & $\mathrm{S}$ & $\mathrm{S}$ & $\mathrm{S}$ & $\mathrm{S}$ \\
\hline $\begin{array}{l}\text { TPST } \\
\text { membuat } \\
\text { pengelolaa } \\
\mathrm{n} \text { sampah } \\
\text { menjadi } \\
\text { baik (Ya/ } \\
\text { Tidak) }\end{array}$ & Ya & Ya & Ya & Ya & $\mathrm{Ya}$ & Ya & Ya \\
\hline $\begin{array}{l}\text { Dampak } \\
\text { Positifnya }\end{array}$ & $\begin{array}{l}\text { Membuka } \\
\text { lapangan } \\
\text { perkejaan }\end{array}$ & $\begin{array}{l}\text { Membuka } \\
\text { lapangan } \\
\text { pekerjaan } \\
\text { dan } \\
\text { menambah } \\
\text { penghasilan }\end{array}$ & $\begin{array}{l}\text { Belum } \\
\text { merasakan } \\
\text { dampaknya }\end{array}$ & $\begin{array}{l}\text { Sampah } \\
\text { tidak } \\
\text { menumpuk } \\
\text { lagi }\end{array}$ & $\begin{array}{l}\text { Sampah } \\
\text { terangkut } \\
\text { dan tidak } \\
\text { ada bau } \\
\text { sampah } \\
\text { lagi }\end{array}$ & $\begin{array}{l}\text { Sampah } \\
\text { lebih } \\
\text { terolah } \\
\text { dengan } \\
\text { baik }\end{array}$ & $\begin{array}{l}\text { Dampaknya } \\
\text { tidak hanya } \\
\text { ke } \\
\text { lingkungan } \\
\text { tapi juga } \\
\text { ekonomi }\end{array}$ \\
\hline Masukan & $\begin{array}{l}\text { Menambah } \\
\text { sarana dan } \\
\text { prasarana } \\
\text { pengangkut } \\
\text { sampah }\end{array}$ & $\begin{array}{l}\text { Meningkatka } \\
\mathrm{n} \text { sosialisasi } \\
\text { ke } \\
\text { masyarakat } \\
\text { untuk } \\
\text { pemilahan } \\
\text { sampah }\end{array}$ & $\begin{array}{l}\text { Menambah } \\
\text { jumlah } \\
\text { sarana dan } \\
\text { prasarana }\end{array}$ & $\begin{array}{l}\text { Menambah } \\
\text { armada dan } \\
\text { lebih rutin } \\
\text { pengangkut } \\
\text { an }\end{array}$ & $\begin{array}{l}\text { Meningkat } \\
\text { kan kinerja } \\
\text { dan } \\
\text { kerjasama } \\
\text { dengan } \\
\text { masyarakat }\end{array}$ & $\begin{array}{l}\text { Libuh rutin } \\
\text { pengambila } \\
\text { n sampah }\end{array}$ & $\begin{array}{l}\text { Lebih gencar } \\
\text { sosialisasi } \\
\text { untuk } \\
\text { meningkatka } \\
\text { n kesadaran } \\
\text { masyarakat }\end{array}$ \\
\hline
\end{tabular}

Sumber Tabel. Jawaban Hasil Survei melalui Google Form (14 Mei 2020)

Dari tujuh sampel yang kamu teliti menunjukan bahwa hampir seluruhnya merasakan dampak positif dari kebijakan tersebut. Mulai dari dampak ekonomi dan dampak pada lingkungan. Dampak ekonominya adalah dengan munculnya lapangan pekerjaan baru bagi masyarakatnya. Serta dampak lingkungannya terlihat jelas bahwa penumpukan sampah di Kelurahan Dadaprejo berkurang drastis dan sampah-sampah tersebut didaur ulang oleh TPST 3R. Namun ada satu responden yang belum merasakan dampak dari kebijakan pembangunan TPST 3R, dikarenakan kurang sosialisasi dari pemerintah kepada masyarakat terkait TPST 3R. Sehingga dari hasil penelitian di Kelurahan Dadaprejo Kota Batu dapat dikatakan bahwa kebijakan tersebut memberikan kepuasan terhadap masyarakat.

Ada beberapa faktor yang menentukan kepuasan terhadap suatu program yaitu komunikasi dan sumber daya. Komunikasi merupakan penyampaian informasi terkait kebijakan tersebut. Komunikasi bisa berupa sosialisasi kepada masyarakat, sehingga masyarakat dapat membantu untuk mencapai 
tujuan atau keberhasilan dan kebijakan tersebut. Dan sumberdaya merupakan aktoraktor yang memalukan pekerjaan terkait pengelolaan sampah. Dengan dimilikinya sumber daya yang baik maka akan memberikan dampak pada kepuasan masyarakat terhadap program (Sari et al., 2018).

Kesesuaian Input dan Output. Kesesuaian input memiliki makna apa yang diharapkan oleh pembuat kebijakan dapat memberikan output yang baik dan sejalan dengan yang diinginkan oleh masyarakat. efektivitas tingkat input dan output dapat dilihat dari perbandingan antara masukan (input) dengan keluaran (output). Indikator kinerja input (masukan) adalah segala sesuatu yang dibutuhkan agar pelaksanaan kegiatan dapat menghasilkan keluaran yang ditentukan; misalnya dana, SDM, informasi. Indikator kinerja output (keluaran) adalah sesuatu yang diharapkan langsung dicapai dari suatu kegiatan yang dapat berupa fisik maupun non fisik Jika output lebih besar dari input maka dapat dikatakan efektif dan sebaliknya jika input lebih besar dari output maka dapat dikatakan tidak efektif. Input dapat berupa modal baik itu sumber daya manusia hingga dana (anggaran) (Fitriani \& Nurcahyanto, 2017). Adapun beberapa kesesuaian input dan output kebijakan pengelolaan sampah di beberapa kota di Indonesia yaitu:

Kesesuaian Input dan Output di Kota Tegal. Anggaran dana yang tidak tercantum dalam APBD juga mempengaruhi efektivitas pengelolaan sampah berbasis TPST karena output (keluaran/target) yang diharapkan pemerintah tentu terbangun TPST yang lengkap dengan sarana dan prasarana yang memadai. Sehingga dapat dikatakan anggaran yang tidak memadai membuat TPST tidak berjalan secara efektif karena harus menggunakan alat seadanya saja (Fitriani \& Nurcahyanto, 2017).

Kesesuaian Input dan Output di Kota Tenggarong. Sumber daya manusia (input) yakni pemerintah daerah (dinas kebersihan dan pertamanan) mampu menyediakan sarana prasarana untuk pengelolaan sampah, selain itu juga tersedia pula petugas sampah dan anggaran dana untuk pengelolaan sampah juga sudah ter anggarkan. Namun output yang dihasilkan bahwa masyarakat masih belum menjalankan kebijakan pengelolaan sampah tersebut. Sehingga tidak hanya dibutuhkan komitmen dari pemerintah akan tetapi juga masyarakat juga harus berkomitmen sehingga dapat berjalan dengan efektif (Sari et al., 2018).

Kesesuaian Input dan Output di Kota Semarang. Kesesuaian input output belum memadai terlihat dari segi input, SDM terutama dari DLH masih kurang di dalam pelaksanaan pengelolaan sampah berbasis TPST, anggaran yang ada juga belum mampu mencukupi sehingga mengalami keterbatasan dalam penyediaan sarana prasarana. Ditambah kondisi masyarakat yang belum sadar akan menjaga lingkungan sehingga membuat kebijakan ini belum berjalan secara efektif (Febryanti \& Suryaningsih, 2017).

Pencapaian Tujuan Menyeluruh. Permasalahan sampah pasti terdapat di setiap daerah, pengelolaan sampah di setiap daerah memiliki bentuk atau cara pengelolaan sampah yang berbeda tergantung dari besaran jumlah dan jenis sampah yang paling banyak dihasilkan oleh masyarakat. Sehingga dalam hal ini pemerintah daerah memiliki kebijakankebijakan tersendiri untuk menyelesaikan permasalahan sampah ini. Masa sekarang ini pengelolaan sampah sudah lebih modern sehingga sampah tidak akan menjadi sepenuhnya sampah yang harus di musnahkan tetapi dapat di olah dan digunakan kembali. Pencapaian tujuan menyeluruh ini dapat dicapai ketika pemerintah dan masyarakat mempunyai kesadaran yang sama-sama tinggi dalam pengelolaan sampah dimana pemerintah optimal dalam memberikan operasional pengelolaan sampah dan masyarakat mempunyai partisipasi yang tinggi. Adapun beberapa pencapaian tujuan menyeluruh di beberapa kota di Indonesia sebagai berikut: 
Pencapaian Tujuan Menyeluruh di Kota Samarinda. Di Kota Samarinda dari total TPST 3R yang ada diperkiraan daya tampung sampah di sepuluh kecamatan tersebut sekitar 1416,1 m3 per hari. Sedangkan sampah yang terkumpul dalam kurun waktu 4 bulan terakhir di tahun 2014 yaitu bulan Juni sampai bulan September, volume sampah yang dihasilkan rata-rata per hari sebesar 3.253 m3 yang tersebar di seluruh Kecamatan di Kota Samarinda. Kemudian pada hasil observasi, didapati volume TPS kurang lagi mendukung dengan volume sampah warga sehingga sampah menggunung dan tercecer keluar TPS. Jadi dapat disimpulkan dalam pelaksanaan kegiatan yang telah di atur dalam perda harus memperhatikan beberapa elemen terkait seperti halnya dalam hal ini jumlah sampah yang mampu di tampung oleh TPS-TPS yang tersebar di seluruh kota, sehingga nantinya perda ini benar-benar dapat menyelesaikan masalah sampah secara sempurna, tidak malah menimbulkan masalah baru di mana lokasi sekitar TPS menjadi tempat yang buruk karena sampah meluber keluar lokasi TPS (Uje et al., 2015).

Pencapaian Tujuan Menyeluruh di Kabupaten Bandung. Kabupaten Bandung sendiri juga telah mengeluarkan aturan khusus terkait pengelolaan sampah, yang pertama ialah Peraturan Daerah Nomor 21 tahun 2009 tentang Pengelolaan Sampah, kemudian terbit pula Peraturan Bupati Nomor 25 tahun 2010 tentang Pengelolaan Sampah, yang kemudian di revisi oleh terbitnya Peraturan Daerah Nomor 15 tahun 2012 tentang Pengelolaan Sampah. Namun permasalahan sampah tetap muncul ketika peraturan peraturan di atas di terapkan dimana keterbatasan sarana dan prasarana yang penting untuk mengangkut menampung dan mengelola sampah seperti contoh Kecamatan Bojongsoang hanya memiliki 2 dump truck untuk mengangkut sampah. Sedangkan container, yakni truk dalam volume yang lebih besar, Kecamatan Bojongsoang sama sekali tidak memilikinya, yang padahal, jumlah timbunan di Bojongsoang hampir bisa dibilang sebagai salah satu yang terbesar, yakni 279 Meter kubik per hari, sedangkan sampah yang terangkut oleh kendaraan hanya sebanyak 49-meter kubik atau dalam persentase yakni sebesar 17,54\%. Partisipasi masyarakat yang rendah untuk membuang sampah pada tempatnya. Partisipasi masyarakat menjadi modal utama dalam pengelolaan sampah ini karena mereka yang menghasilkan sampah, jika kesadaran masyarakat tinggi dan peranan pemerintah aktif maka permasalahan sampah dapat di atasi dalam hal ini (Febiana, 2019).

\section{Faktor Pendukung dan Penghambat Efektivitas Pengelolaan Sampah Berbasis TPST 3R di Indonesia \\ Faktor Pendukung: 1) Pemberian}

fasilitas dan sarana prasarana dari pemerintah. Pemberian fasilitas dan sarana prasarana yang diberikan oleh pemerintah dapat berupa petugas kebersihan, petugas pengangkut sampah, kendaraan pengangkut sampah, pick-up, dump truck, excavator menyediakan tempat pembuangan sampah sementara dan menyediakan tempat pembuangan akhir, alat pencacah sampah organik, alat pemisah sampah dan berbagai sarana dan prasaran lain yang dapat menunjang kinerja di dalam pengelolaan sampah pada TPST 3R; 2) Pendampingan secara rutin oleh dinas terkait kepada masyarakat. Pemerintah melalui Dinas Lingkungan Hidup maupun dinas-dinas lain yang terkait dapat memberikan pendampingan secara rutin kepada masyarakat misalnya pemberian sosialisasi untuk memberikan penyadaran kepada masyarakat akan tanggung jawab mereka berpartisipasi dalam pengelolaan sampah dimulai dari lingkup terkecil. Selain itu dinas juga harus memantau kinerja pengelolaan sampah di TPST itu sendiri agar tetap sesuai rencana.

Faktor Penghambat: 1) Anggaran yang tidak memadai terutama dari APBD. 
Penyediaan sarana dan prasarana dalam pengelolaan sampah terutama TPST 3R yang harus memilah antara sampah organik dan anorganik membutuhkan anggaran yang tidak sedikit, misalnya saja di Kota Batu menganggarkan Rp.300 juta untuk satu mesin pengolah sampah, sedangkan alat yang dibutuhkan sebanyak 5 unit. Otomatis ini membutuhkan penganggaran yang banyak, juga tidak jarang menunggu anggaran dari periode tahun depan sehingga harus menunggu beberapa saat membuat pengolah sampah menjadi tidak berjalan efektif; 2) Tidak ada bimbingan secara teknis kepada masyarakat dalam pengelolaan sampah. Sosialisasi dinas terkait akan tanggung jawab pengelolaan sampah tidak dibarengi dengan pelatihan atau bimbingan secara teknis, sehingga partisipasi masyarakat terhenti pada kesadaran pengelolaan sampah saja namun tidak berlanjut pada bagaimana cara proses pengelolaannya secara teknis; 3) Partisipasi dan kesadaran masyarakat akan pentingnya pengelolaan sampah rendah. Berbagai sosialisasi dan pendampingan yang dilakukan juga tidak berdampak banyak kepada partisipasi masyarakat. Kurangnya sosialisasi ke masyarakat akan adanya TPST 3R di lingkungan mereka. Keberadaan TPST yang seringkali jauh dari permukiman warga membuat warga tidak menyadari akan keberadaan TPST 3R, sehingga diperlukan sosialisasi kepada masyarakat sehingga ketika masyarakat mengetahui keberadaan TPST 3R setidaknya akan berpartisipasi dalam pemisahan sampah hasil rumah tangga atau di dalam pengelolaannya.

\section{SIMPULAN}

Efektivitas kebijakan pengelolaan sampah berbasis TPST 3R di Indonesia masih belum optimal dalam pelaksanaannya. Efektivitas kebijakan pengelolaan sampah tersebut diukur melalui keberhasilan program, keberhasilan sasaran, kepuasan terhadap program, kesesuaian input dan output, dan pencapaian tujuan menyeluruh. Keberhasilan program yang dikeluarkan oleh pemerintah terkait pengelolaan sampah berbasis TPST 3R di Indonesia masih sangat jauh dari kata keberhasilan. Hal tersebut dilihat dari beberapa daerah yang menerapkan sistem pengelolaan sampah berbasis TPST 3R belum maksimal. Mulai dari Reduce (mengurai), Reuse (menggunakan kembali), Recycle (mendaur ulang sampah). Keberhasilan sasaran terkait pengelolaan sampah berbasis TPST 3R di beberapa wilayah di Indonesia sudah cukup maksimal. Sasaran dari pembangunan TPST 3R adalah untuk mengurangi penumpukan sampah serta sampah dapat menjadi bahan yang memiliki nilai jual dan dapat digunakan kembali. Beberapa wilayah yang telah menerapkan pengelolaan sampah berbasis TPST 3R mengalami penurunan jumlah penumpukan sampah di TPA (Tempat Pembuangan Akhir).

Kepuasan terhadap program pengelolaan sampah berbasis TPST 3R dikatakan belum cukup maksimal. Karena masih banyak masyarakat di daerah-daerah yang menerapkan TPST 3R belum memahami apa itu 3R sehingga masyarakat belum terlibat aktif dalam mengurangi jumlah sampah di Indonesia. Serta kepuasan masyarakat terhadap program tersebut diakibatkan kurangnya komunikasi atau sosialisasi dari pemerintah terkait pengelolaan sampah berbasis TPST 3R. Kesesuaian input dan output dari program TPST 3R ini belum maksimal dikarenakan SDM dan anggaran yang belum memadai sehingga untuk mencapai output yang diharapkan sangat susah. Outputnya susah digapai karena dalam menerapkan pengelolaan sampah berbasis TPST 3R masih menggunakan alat-alat yang belum memadai. Pencapaian tujuan menyeluruh dari penerapan pengelolaan sampah berbasis TPST 3R belum seluruhnya tercapai. Karena beberapa faktor penghambat yang masih ditemui dalam pelaksanaan kebijakan yakni pemerintah yang kurang memadai dari segi operasional dan masyarakat yang memiliki partisipasi rendah.

\section{DAFTAR PUSTAKA}

Budi Setianingrum, R. (2018). Pengelolaan Sampah Dengan Pola 3 R Untuk Memperoleh Manfaat Ekonomi Bagi Masyarakat. BERDIKARI : Jurnal Inovasi Dan Penerapan Ipteks, 6(2), 173-183.

https://doi.org/10.18196/bdr.6244

Den. (2020). Ada Papan Larangan, Tetap Saja Buang Sampah. Radar Cirebon. https://www.radarcirebon.com/2020/05/0 
9/ada-papan-larangan-tetap-saja-buangsampah/

Dwi Febria Zulfa, Eriyanti, F., \& Khaidir, A. (2019). Efektivitas Program Desaku Menanti Bagi Warga Binaan Sosial (WBS) di Kota Padang. Ranah Research: Journal of Multidisciplinary Research and Development, 1(2), 210-217.

Febiana, R. M. R. M. (2019). Implementasi Peraturan Daerah Kabupaten Bandung Nomor 15 Tahun 2012 Tentang Pengelolaan Sampah (Studi Kasus Pengelolaan Sampah oleh Dinas Lingkungan Hidup di Kecamatan Bojongsoang, Kabupaten Bandung). Jurnal Ilmu Sosial Dan Ilmu Politik, 3(1), 114-124. http://ejournal.unibba.ac.id/index.php/jisip ol/article/download/11/10/\#pdfjs.action=d ownload

Febryanti, I., \& Suryaningsih, M. (2017). Implementasi Kebijakan Penanganan Sampah di Kota Semarang berdasarkan Peraturan Daerah Kota Semarang Nomor 6 Tahun 2012 tentang Pengelolaan Sampah. Journal of Public Policy and Management Review, 7(1), 26-38. https://doi.org/10.1017/CB097811074153 24.004

Fitriani, I., \& Nurcahyanto, H. (2017). Evaluasi Program Pengembangan Kinerja Pengelolaan Persampahan Di Kota Tegal. Journal of Public Policy and Management Review, 6(2), 177188.

Isril, \& Febrina, R. (2017). Problematika Manajemen Pengelolaan Sampah Kota Pekanbaru Tahun 2016. Nakhoda: Jurnal Ilmu Pemerintahan, 16(27),

$13-31$. https://doi.org/10.35967/jipn.v16i27.5792

Momentum. (2020). Wakil Rakyat Dapil 3 Junrejo, Seriusi Keluhan Warga Soal TPA Tlekung. Momentum.Com. https://memontum.com/107193-wakilrakyat-dapil-3-junrejo-seriusi-keluhanwarga-soal-tpa-tlekung

Nugraheni, A. . P., \& Widjonarko, W. (2019). Keberlanjutan Tempat Pengolahan Sampah Terpadu Di Desa Tawangsari, Kabupaten Boyolali. Teknik PWK (Perencanaan Wilayah Kota), 8(4), 209-216. http://ejournal3.undip.ac.id/index.php/pwk

Pradityo, S., Gandhi, G., \& Prastiwi, A. M. (2019). Kelola Sampah Mulai dari Rumah. Katadata.Co.Id.

https://katadata.co.id/0/analisisdata/5e9a5 7af981c1/kelola-sampah-mulai-dari-rumah

Rendy, M. (2015). Evaluasi Kebijakan Pengelolaan Sampah Di Dinas Kebersihan Dan Pertanaman Kota Palu. E-Jurnal Katalogis, 3(11), 73-79.

Sahputra, B. S., \& Srihardjono, N. B. (2018). Pemberdayaan Masyarakat Dalam Pengelolaan Sampah Di Tpst 3R-Desa Mulyo Agung. JISIP: Jurnal Ilmu Sosial Dan Ilmu Politik, 7(3), 6-12.

Sari, R., Resmawan, E., \& Alaydrus, A. (2018). Implementasi Kebijakan Peraturan Daerah Kabupaten Kutai Kartanegara Nomor 4 Tahun 2014 Tentang Pengelolaan Sampah Rumah Tangga Dan Sampah Sejenis Sampah Rumah Tangga Di Kota Tenggarong. EJournal Ilmu Pemerintahan, 6(3), 1195-1208.

Suning, \& Muryanto, D. (2016). Kebijakan Keberlanjutan Pengolahan Persampahan Kabupaten Sidoarjo Berbasis TPST. Jurnal Teknik WAKTU, 14(01).

Uje, L., Fitriyah, N., \& Paselle, E. (2015). Evaluasi Peraturan Daerah Nomor 02 Tahun 2011 Tentang Pengelolaan Sampah Di Kota Samarinda. Jurnal Administrative Reform, 3(02), 288-301. 